\title{
THE RISK FACTORS OF MENSTRUATION CYCLE AND LIFESTYLE TO THE PREVALENCE OF THE OVARY CYST IN GENERAL HOSPITAL DISTRICT IN KONAWE
}

\author{
Putu Suri Saraswati ${ }^{1 *}$, Muh. Abd. Gafur Tirtayasa Mangidi ${ }^{1}$, Astuti Widyasningrum ${ }^{1}$, \\ Tasnim Tasnim ${ }^{1}$
}

\section{College of Health Sciences Mandala Waluya Kendari, Southeast Sulawesi, Indonesia}

* Correspondence

Putu Suri Saraswati

Master of Public Health, STIKES Mandala Waluya

Jl. Jend. AH. Nasution, Kambu, Kendari, Southeast Sulawesi

E-mail: surisaraswati@gmail.com

\begin{abstract}
Background: In Indonesia the incidence of ovarian cysts in 2015 as many as 23,400, people are expected to die as many as 13,900 people $(59.40 \%)$. Preliminary studies shows that in BLUDs Konawe Hospital, Medical Records Data Obtained data on cases of ovarian cysts in 2016 as many as 57 people, in 2017 were 62 people, while In 2018, there were 87 cases. The purpose of this study was to Determine the risk factors for ovarian cysts at the Regional Public Service Board of Konawe Hospital.
\end{abstract}

Methods:This is a case control study. The population of the case were all the Patients with ovarian cyst in 2018 as many as 106 people. Population control Patients were all admitted in Midwifery both outpatient and inpatient undiagnosed ovarian cyst in 2018 as many as 1,396 people. Sampling was done by simple random sampling. Controls were taken by purposive sampling method using a matching age. Data were collected through questionnaires and Analyzed using odds ratios (OR).

Results: The results Showed that the odds ratio of the menstrual cycle $=2,918$ and lifestyle with $\mathrm{OR}=12$ 969. Therefore the value of the odds ratio $(\mathrm{OR} \geq 1)$ then all variables are risk factors for the incidence of ovarian cysts.

Conclusion: Conclusion of this study is menstrual cycles and lifestyle being the risk factor to the incidence of ovarian cysts in BLUDs Konawe.

Keywords: lifestyle; menstrual cycle; ovarian cysts 


\section{INTRODUCTION}

Ovarian cyst is a disease of the female reproductive organ disorders (1). Ovarian cyst is a benign gynecological tumors most often found in women in their reproductive period (2). The formation of ovarian cysts itself caused the heredity of families experiencing cysts, can be caused also by irregular menstrual cycles, and their patients with hypothyroidism (3). In most cases we are usually not aware of any ovarian cysts in the body, because basically ovarian cysts do not cause any symptoms (4).

Based on the Indonesian Demographic and Health Survey in 2014, the incidence of ovarian cysts ranks sixth dangerous of reproductive system disorders in women after cervical carcinoma, uterine, breast, colorectal, skin and lymphoma (5). Ovarian cyst is a leading cause of death in cases of gynecological malignancy today (6). Ovarian cysts are the fifth most common cancer that causes death in women after lung cancer, kolorental, breast and pancreas (7). The cause of death in the case of gynecological malignancy. The incidence of ovarian cysts in Indonesia in 2015 as many as 23,400 people are expected to die as many as 13,900 people $(59.40 \%)$. This high mortality due to the disease is initially asymptomatic and have sparked complaints when it occurs so that $60-70 \%$ of metastatic patients present at an advanced stage (8).

From medical records in hospitals BLUDs Bahteramas number of visits to both outpatient and inpatient especially in obstetrics space in 2017 as many as 1,762 people, from the data of patients with ovarian cysts as many as 31 people or about $1.75 \%$ of cases. Based on preliminary studies that researchers do in BLUDs Konawe Hospital, the Medical Record Data obtained data on the number of patients in cases of ovarian cysts in 2016 as many as 57 people, in 2017 as many as 62 people, while In 2018, there were 
87 cases. Occurrence of such cases caused by not knowing the exact cause of the occurrence of cases of ovarian cysts.

\section{METHOD}

This type of research is quantitative by using a case-control design May to August 2019. The data collection technique was a questionnaire (9). The population for the case that is 106 people. Population control as many as 1,396 people (10). From the calculation of the samples, the obtained sample at a minimum of 94 samples. The control sample with a sample size of comparable cases as much as 94 people (11). A questionnaire was used as the method of data collection in order to obtain information in accordance with the purpose retrospective researchers.

\section{RESULT}

Variable Odds Ratio menstrual cycle (menstrual cycle on the incidence of ovarian cysts) at the (CI) $95 \%$, obtained by OR of 2.918 . This means that women who have a normal menstrual cycle 2,918 times greater risk of suffering from ovarian cysts compared to women with normal menstrual cycles. Because the value of $\mathrm{OR}>1$, it can be concluded that the abnormal menstrual cycle can be considered as a potential risk factor of ovarian cysts. Lifestyle variables Odds Ratio, OR obtained at 12.969. This means that women whose lifestyles are not healthy (risk) have 2,918 times greater risk of suffering from ovarian cysts compared to women with a healthy lifestyle (no risk). Because the value of OR> 1, it can be concluded that the lifestyle can be considered as a potential risk factor of ovarian cysts. 
As for the relationship of risk factors with the incidence of menstrual cycle ovarian cysts in the General Services Agency (BLUD) Konawe, Southeast Sulawesi, can be seen in the following table:

Table 1

Menstrual Cycle Relationship Risk Factors Against Ovarian Cysts incident in BLUDs RS Konawe

\begin{tabular}{|c|c|c|c|c|c|c|c|c|c|c|}
\hline \multirow{3}{*}{$\begin{array}{l}\text { Menstrual } \\
\text { cycle }\end{array}$} & \multicolumn{4}{|c|}{ Genesis Cysts } & \multirow{2}{*}{\multicolumn{2}{|c|}{ Total }} & \multirow{3}{*}{$\mathbf{X}^{2}$} & \multirow{2}{*}{ OR } & \multicolumn{2}{|c|}{ CI } \\
\hline & \multicolumn{2}{|c|}{ Case } & \multicolumn{2}{|c|}{ Control } & & & & & Lower & Upper \\
\hline & $\mathbf{n}$ & $\%$ & $\mathbf{n}$ & $\%$ & $\mathbf{n}$ & $\%$ & & \multirow{4}{*}{2,918} & \multirow{4}{*}{1,601} & \multirow{4}{*}{5.321} \\
\hline risk & 52 & $65 \%$ & 28 & $35 \%$ & 80 & $100 \%$ & \multirow{3}{*}{11.511} & & & \\
\hline no risk & 42 & $39 \%$ & 66 & $61 \%$ & 108 & $100 \%$ & & & & \\
\hline Total & 94 & $50 \%$ & 94 & $50 \%$ & 188 & $100 \%$ & & & & \\
\hline
\end{tabular}

Any links lifestyle risk factors with the incidence of ovarian cysts in BLUDs RS Konawe can be seen in the following table:

Table 2

Relationships Lifestyle Risk Factors Against Ovarian Cysts incident in BLUDs RS Konawe

\begin{tabular}{|c|c|c|c|c|c|c|c|c|c|c|}
\hline \multirow{3}{*}{ Lifestyle } & \multicolumn{4}{|c|}{ Genesis Cysts } & \multirow{2}{*}{\multicolumn{2}{|c|}{ Total }} & \multirow{2}{*}{$\mathbf{X}^{2}$} & \multirow{2}{*}{ OR } & \multicolumn{2}{|c|}{ CI } \\
\hline & \multicolumn{2}{|c|}{ Case } & \multicolumn{2}{|c|}{ Control } & & & & & Lower & Upper \\
\hline & $\mathbf{n}$ & $\%$ & $\mathbf{n}$ & $\%$ & $\mathbf{n}$ & $\%$ & \multirow{4}{*}{41.121} & \multirow{4}{*}{12.969} & \multirow{4}{*}{5.435} & \multirow{4}{*}{30.948} \\
\hline risky & 87 & $65 \%$ & 46 & $35 \%$ & 133 & $100 \%$ & & & & \\
\hline no risk & 7 & $13 \%$ & 48 & $87 \%$ & 55 & $100 \%$ & & & & \\
\hline Total & 94 & $50 \%$ & 94 & $50 \%$ & 188 & $100 \%$ & & & & \\
\hline
\end{tabular}

\section{DISSCUSION}

Menstrual Cycle Risk Factors relationship with Genesis Ovarian Cysts in BLUDs

\section{RS Konawe}

During the menstrual cycle, the amount of estrogen and progesterone produced by the ovaries changed (12). The first part of the menstrual cycle that is produced by the ovaries are mostly estrogen (13). This estrogen which will cause the growth of a layer of thick blood and tissue around each of the endometrium (14). At mid-cycle, the ovaries release an egg is called ovulation. The second part of the menstrual cycle, which is 
between the mid- to come next menstruation, a woman's body produces the hormone progesterone prepare the uterus for pregnancy (15).

Odds Ratio calculation results (the menstrual cycle on the incidence of ovarian cysts) at the (CI) $95 \%$, obtained by OR of 2.918 . This means that women who have a normal menstrual cycle 2,918 times greater risk of suffering from ovarian cysts compared to women with normal menstrual cycles. Because the value of OR> 1 , it can be concluded that the abnormal menstrual cycle can be considered as a potential risk factor of ovarian cysts.

This research line, the results of research conducted by (16), Bahwasannya, cysts can also form if the abnormal ovarian function leads to accumulation of follicles imperfectly formed in the ovaries. The follicles do not ovulate due to hormone levels of FSH lower and LH hormone high in circumstances that remain have led to the formation andorogen and estrogen by the follicles and adrenal gland resulting in the follicles of anovulatory follicle failed maturation and fail to release an egg, formed imperfectly in ovarian cysts because it is formed in the ovaries.

\section{Lifestyle Risk Factors relationship with Genesis Ovarian Cysts in BLUDs Konawe}

The results showed that of the 133 respondents risky lifestyle are 87 respondents $(65 \%)$ who suffered from ovarian cysts. Unhealthy lifestyle such as patterns of consumption, unhealthy diet such as eating foods high in fat, can lead to obesity (17). Obesity may increase the occurrence of cysts on the ovary enlargement, because the obese are fat tissue in the body that can be converted into estrogen (18). Furthermore, an increase in the hormone estrogen in the body that can lead to enlargement of cysts on 
the ovaries (19). Unhealthy lifestyle sepertikurangnya exercise and smoking also may be risk factors for ovarian cyst enlargement (20).

These results can also be seen from the analysis Odds Ratio, OR obtained at 12.969. This means that women whose lifestyles are not healthy (risky) has 2,918 times greater risk of suffering from ovarian cysts compared to women with a healthy lifestyle (no risk). Because the value of $\mathrm{OR}>1$, it can be concluded that the lifestyle can be considered as a potential risk factor of ovarian cysts. This research is in line with research in space KRMT Wongsonegoro Gynecology Hospital Semarang which states that a sedentary lifestyle is one of the factors that can cause ovarian cysts (21).

\section{CONCLUSIONS}

Menstrual cycle is a risk factor for the occurrence of ovarian cysts at BLUD Konawe Hospital. Beside that lifestyle also is a risk factor for the occurrence of ovarian cysts at BLUD Konawe Hospital. So it is expected that the central government can design a program to implement early detection of ovarian cyst symptoms, so that ovarian cyst management can be done immediately and not progress to an advanced stage. It is expected that the community (women) can adopt a healthy lifestyle by not smoking, not consuming alcohol, reducing consumption of fat intake, or eating healthy foods such as vegetables and fruit.

\section{REFERENCES}

1. Alcazar JL, Martinez N, Juez L, Caparros M, Salas A, Errasti T. Ovarian simple cysts in asymptomatic postmenopausal women detected at transvaginal ultrasound: A review of literature. World Journal of Obstetrics and Gynecology. 2015;4(4):108-12.

2. Kemenkes RI. Rencana strategis kementerian kesehatan tahun 2010-2014. Jakarta: Kementerian Kesehatan Republik Indonesia. 2010. 
3. Abduljabbar HS, Bukhari YA, Al Hachim EG, Ashour GS, Amer AA, Shaikhoon MM, et al. Review of 244 cases of ovarian cysts. Saudi medical journal. 2015;36(7):834.

4. Perumal J, Balasundaram G, Mahyuddin AP, Choolani M, Olivo M. SERS-based quantitative detection of ovarian cancer prognostic factor haptoglobin. International journal of nanomedicine. 2015;10:1831.

5. SDKI. Profil Kesehatan Indonesia. Jakarta: Kementrian Kesehatan Republik Indonesia; 2014.

6. Thomsen LH, Schnack TH, Buchardi K, Hummelshoj L, Missmer SA, Forman A, et al. Risk factors of epithelial ovarian carcinomas among women with endometriosis: a systematic review. Acta obstetricia et gynecologica Scandinavica. 2017;96(6):761-78.

7. Guo S-W, Ding D, Shen M, Liu X. Dating endometriotic ovarian cysts based on the content of cyst fluid and its potential clinical implications. Reproductive Sciences. 2015;22(7):873-83.

8. Kemenkes RI. Rencana Strategis Kementerian Kesehatan Tahun 2015-2019. Jakarta: Kementerian Kesehatan RI; 2015.

9. Ismail HF. Statistika Untuk Penelitian Pendidikan dan Ilmu-Ilmu Sosial: Kencana; 2018.

10. Profil BLUD RS Konawe. Profil Badan Layanan Umum Rumah Sakit Konawe. Konawe2017.

11. Lemeshow S, Hosmer DW, Klar J, Lwanga SK. Besar sampel dalam penelitian kesehatan. Yogyakarta: Gajah Mada University. 1997.

12. Baba T, Kang HS, Hosoe Y, Kharma B, Abiko K, Matsumura N, et al. Menstrual cyclic change of metastin/GPR54 in endometrium. Medical molecular morphology. 2015;48(2):76-84.

13. Prathita YA, Syahredi S, Lipoeto NI. Hubungan Status Gizi dengan Siklus Menstruasi pada Mahasiswi Fakultas Kedokteran Universitas Andalas. Jurnal Kesehatan Andalas. 2017;6(1):104-9.

14. Oktaviana RR, Wulandari P, Solechan A. Faktor-Faktor Yang Berhubungan Dengan Keteraturan Siklus Menstruasi Pada Siswi Di SMP N 23 Semarang. Karya Ilmiah. 2017;9.

15. Deswani UD, Mulyanti Y. Asuhan Keperawatan Prenatal Dengan Pendekatan Neurosains: WINEKA MEDIA; 2019.

16. Akbar B. Tumbuhan dengan kandungan senyawa aktif yang berpotensi sebagai bahan antifertilitas. 2013 .

17. Wadden TA, Bray GA. Handbook of obesity treatment: Guilford Publications; 2018 .

18. Iskandar A, Mayashinta DK, Indra MR. Mengenal Toxoplasma Gondii, Obesitas, dan Sindrom Metabolik: Universitas Brawijaya Press; 2018. 
19. Heymsfield SB, Wadden TA. Mechanisms, pathophysiology, and management of obesity. New England Journal of Medicine. 2017;376(3):254-66.

20. Suma MR, Sari NMN. Penerapan Penerapan Self Hypnosis Pada Ny "SW" Umur 40 Tahun dengan Kista Ovarium (Penatalaksanaan pada Gangguan Reproduksi dengan Kista Ovarium di Ruang Dara RSUD Wangaya). Journal Center of Research Publication in Midwifery and Nursing. 2017;1(2).

21. Laelati S. Asuhan Kebidanan Gangguan Reproduksi Pada Ny. S Umur 29 Tahun Dengan Kista Ovarium Di Ruang Ginekologi Rsud Krmt Wongsonegoro Kota Semarang: Universitas Muhammadiyah Semarang; 2017. 